\title{
Pseudonocardia adelaidensis sp. nov., an endophytic actinobacterium isolated from the surface-sterilized stem of a grey box tree (Eucalyptus microcarpa)
}

\author{
Onuma Kaewkla and Christopher M. M. Franco
}

Correspondence

Christopher M. M. Franco

Chris.Franco@flinders.edu.au

\author{
Department of Medical Biotechnology, School of Medicine, Flinders University, Bedford Park, \\ South Australia 5042, Australia
}

\begin{abstract}
An aerobic, actinobacterial strain with rod-shaped spores, EUM $221^{\top}$, which was isolated from the surface-sterilized stem of a grey box tree (Eucalyptus microcarpa), is described. Phylogenetic evaluation based on 16S rRNA gene sequence similarity showed that this isolate belongs to the family Pseudonocardiaceae, with the closest neighbour being Pseudonocardia zijingensis $6330^{\top}$ (98.7\%). The level of $16 \mathrm{~S}$ rRNA gene sequence similarity between the isolate and species of the genus $P$ seudonocardia with validly published names ranged from 95 to $98 \%$. Chemotaxonomic data (meso-diaminopimelic acid; major menaquinone $\mathrm{MK}-8\left(\mathrm{H}_{4}\right)$; major fatty acid iso- $\mathrm{C}_{16: 0}$ ) confirmed the affiliation of strain EUM $221^{\top}$ to the genus Pseudonocardia. The results of the phylogenetic analysis, including physiological and biochemical studies in combination with DNADNA hybridization, allowed the genotypic and phenotypic differentiation of strain EUM $221^{\top}$ from the closest described species. Therefore, this strain represented a novel species and the name proposed is Pseudonocardia adelaidensis sp. nov. The type strain is EUM $221^{\top}$ (=DSM $45352^{\top}$ $=$ ACM $5286^{\top}$ ).
\end{abstract}

The genus Pseudonocardia was originally proposed by Henssen (1957). Phylogenetic analysis shows that this genus forms a consistent cluster within the evolutionary radiation of the family Pseudonocardiaceae (Lee et al., 2000; McVeigh et al., 1994; Reichert et al., 1998; Warwick et al., 1994). Members of the genus are non-motile and their aerial mycelium fragments to form chains of straight or zigzag spores. Chemotaxonomic characteristics show a lack of mycolic acids and a type IV cell wall containing meso-diaminopimelic acid (meso- $\left.\mathrm{A}_{2} \mathrm{pm}\right)$, arabinose and galactose. The major menaquinone is $\mathrm{MK}-8\left(\mathrm{H}_{4}\right)$, the phospholipid pattern is type PII or PIII and iso-branched hexadecanoic acid (iso- $\mathrm{C}_{16: 0}$ ) is the predominant fatty acid. The DNA G $+\mathrm{C}$ content is in the range $68-79 \mathrm{~mol} \%$. At the time of writing, the genus comprises 31 species with validly published names (Euzéby, 1997).

During the course of our research on molecular and culture-based methods to identify endophytic actinobacteria (Coombs \& Franco, 2003; Conn \& Franco, 2004), we

Abbreviation: $A_{2} p m$, diaminopimelic acid.

The GenBank/EMBL/DDBJ accession number for the $16 \mathrm{~S}$ rRNA gene sequence of strain EUM $221^{\top}$ is FJ805427.

An extended maximum-parsimony tree and a neighbour-joining tree based on 16S rRNA gene sequences and a scanning electron micrograph of spores of strain EUM $221^{\top}$ are available as supplementary material with the online version of this paper. have studied populations and identified novel strains of actinobacteria from native Australian plants. In this report, the description of the morphological, physiological, chemotaxonomic and phylogenetic characteristics of a Pseudonocardia-like strain, EUM $221^{\mathrm{T}}$, is presented. Phenotypic and genotypic data show that this strain represents a novel species.

Strain EUM $221^{\mathrm{T}}$ was isolated from the internal tissue of a surface-sterilized stem sample of a grey box tree (Eucalyptus microcarpa) which was collected from the grounds of Flinders University. Samples were processed within $4 \mathrm{~h}$ of collection by using the following procedure, according to Kaewkla \& Franco (2010). Briefly, the bark of the stems was removed and samples were sterilized with $70 \%$ ethanol and $6 \%$ sodium hypochlorite for $5 \mathrm{~min}$ each and sterile $10 \% \mathrm{NaHCO}_{3}$ for $10 \mathrm{~min}$. Crushed plant tissues were plated onto 10 isolation media. All media were adjusted to pH 7.2 and media were supplemented with $20 \mu \mathrm{g}$ nalidixic acid $\mathrm{ml}^{-1}$ and $100 \mathrm{U}$ nystatin $\mathrm{ml}^{-1}$ to repress the growth of bacteria and fungi, respectively. Plates were kept in sealed plastic boxes, which contained moist paper towels to maintain moisture, and incubated at $27{ }^{\circ} \mathrm{C}$. After incubation for 8 weeks, a Pseudonocardia-like strain, EUM $221^{\mathrm{T}}$, emerged from a surface-sterilized stem sample which was placed on VL 70 medium with a mixture of Dgalacturonate, D-glucuronate, L-ascorbate and D-gluconate (GGAG) at concentrations of $0.5 \mathrm{mM}$ of each growth 
substrate (Joseph et al., 2003; Schoenborn et al., 2004). This strain was purified and maintained on half-strength potato dextrose agar (HPDA).

Extraction of genomic DNA and PCR amplification and sequencing of the 16S rRNA gene from strain EUM $221^{\mathrm{T}}$ were achieved as described previously by Coombs \& Franco (2003). The resultant nearly full-length 16S rRNA gene sequence (1412 bp) was aligned manually to the GenBank databases by using BLAST (Altschul et al., 1997) and the result showed that strain EUM $221^{\mathrm{T}}$ was closely related to members of the genus Pseudonocardia. The sequence of this strain was multiply aligned with $16 \mathrm{~S}$ rRNA gene sequences available from GenBank/EMBL/DDBJ of representatives of the closest related genus by using the CLUSTAL_X program (Thompson et al., 1997). Phylogenetic trees were constructed by the neighbour-joining (Saitou \& Nei, 1987) and maximum-parsimony (Kluge \& Farris, 1969) tree-making methods by using the software package MEGA version 4 (Tamura et al., 2007). Pairwise distances for the neighbourjoining algorithm were calculated according to Kimura's two-parameter model (Kimura, 1980) and Min-mini heuristic with search factor of 1 was applied in maximum-parsimony analysis. The topology of the tree was evaluated by performing a bootstrap analysis (Felsenstein, 1985) based on 1000 replications.

Strain EUM $221^{\mathrm{T}}$ showed the highest $16 \mathrm{~S}$ rRNA gene sequence similarity to Pseudonocardia zijingensis $6330^{\mathrm{T}}$ ( $98.7 \%$, a value that corresponds to 16 differences over 1412 locations). The strain shared 95-98 \% 16S rRNA gene sequence similarity with all other Pseudonocardia species with validly published names. The phylogenetic position of strain EUM $221^{\mathrm{T}}$ was evaluated, showing clearly that strain EUM $221^{\mathrm{T}}$ was a member of the genus Pseudonocardia within the family Pseudonocardiaceae. The affiliation

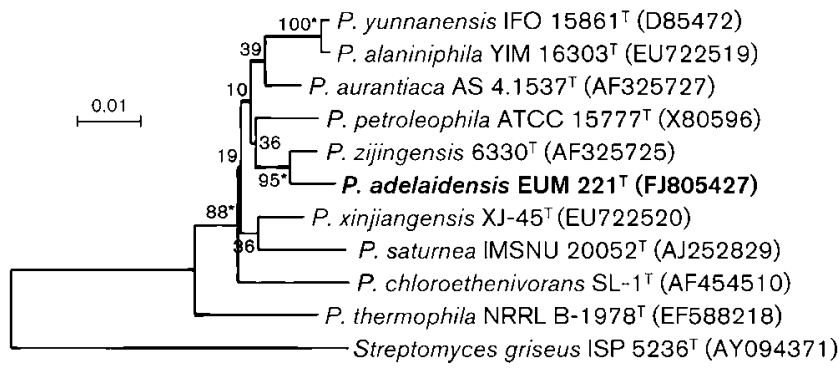

Fig. 1. Neighbour-joining tree showing the relationship between strain EUM $221^{\top}$ and closely related members of the genus Pseudonocardia based on 16S rRNA gene sequences. Streptomyces griseus ISP $5236^{\top}$ was used as the outgroup. Asterisks indicate branches of the tree that were also recovered by using the maximum-parsimony algorithm (Supplementary Fig. S1). Bootstrap percentages based on 1000 resamplings are listed at nodes. Bar, 0.01 changes per nucleotide position. A tree including a wider selection of reference strains is available as Supplementary Fig. S2. between strain EUM $221^{\mathrm{T}}$ and its closest neighbour, $P$. zijingensis $6330^{\mathrm{T}}$, was supported by both the neighbourjoining and maximum-parsimony algorithms, with bootstrap values of 97 and $96 \%$, respectively (Fig. 1 and Supplementary Fig. S1, available in IJSEM Online). A neighbour-joining tree incorporating strain EUM $221^{\mathrm{T}}$ and representatives of all species of the genus with validly published names is presented as Supplementary Fig. S2.

The $\mathrm{G}+\mathrm{C}$ content of the genomic DNA of strain EUM $221^{\mathrm{T}}$ was determined by HPLC as described by Mesbah et al. (1989). The result showed that the DNA G+C content was $78.8 \mathrm{~mol} \%$.

DNA-DNA relatedness experiments were carried out between strain EUM $221^{\mathrm{T}}$ and its closest phylogenetic neighbour, $P$. zijingensis DSM $44774^{\mathrm{T}}$, by measuring the divergence between the thermal denaturation midpoint of homoduplex DNA and heteroduplex DNA $\left(\Delta T_{\mathrm{m}}\right)$, as described by Gonzalez \& Saiz-Jimenez (2005). The result showed that strain EUM $221^{\mathrm{T}}$ represented a distinct taxon, as the DNA-DNA relatedness analyses revealed differences in melting temperature of $6{ }^{\circ} \mathrm{C}$ with its closest phylogenetic neighbour, which corresponds to $60 \%$ relatedness, which is well below the $70 \%$ guideline recommended for the delineation of genomic species (Wayne et al., 1987; Rosselló-Mora \& Amann, 2001).

For chemotaxonomic analyses, strain EUM $221^{\mathrm{T}}$ and the type strains $P$. zijingensis DSM $44774^{\mathrm{T}}$ and Pseudonocardia yunnanensis DSM $44253^{\mathrm{T}}$ were studied together for comparative purposes. For the analysis of whole-cell fatty acids, cells of all strains were grown for 10 days at $25{ }^{\circ} \mathrm{C}$ in TSB at 150 r.p.m. and harvested and washed by repeated centrifugation in sterile water. Wet cells $(100 \mathrm{mg})$ were saponified and methylated and the fatty acid methyl esters (FAMEs) were analysed using the MIDI (Microbial Identification) system (Sasser, 2001). Extraction and purification of isoprenoid quinones were performed using the method of Collins et al. (1977) and samples were analysed by reversed-phase LC-MS employing UV detection and electrospray mass spectrometry (ESI). The solvent system was 2-propanol/methanol $(1: 1)$ at a flow rate of

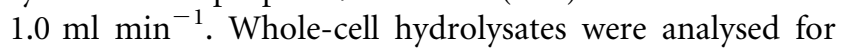
$\mathrm{A}_{2} \mathrm{pm}$ isomers (Bousfield et al., 1985) and for sugars using the method of Hasegawa et al. (1983). Mycolic acids were determined according to Minnikin et al. $(1975,1980)$ and acyl cell-wall analysis was performed according to Uchida et al. (1999). The results showed that the $\mathrm{A}_{2} \mathrm{pm}$ in wholecell hydrolysates of strain EUM $221^{\mathrm{T}}$ was in the meso configuration and that the whole-cell sugars were arabinose and galactose. These data confirmed that strain EUM $221^{\mathrm{T}}$ belongs to the family Pseudonocardiaceae, members of which have type IV cell walls. Whole cells were of the nonmycolic acid type and acetyl type. Strain EUM $221^{\mathrm{T}}$ contained MK- $8\left(\mathrm{H}_{4}\right)$ as the predominant menaquinone; no other menaquinone components could be detected. The whole-cell fatty acids of EUM $221^{\mathrm{T}}$ were of the iso- and anteiso-branched type. The major fatty acid was iso- $\mathrm{C}_{16: 0}$ 
Table 1. Whole-cell fatty acid compositions of strain EUM $221^{\top}$ and related Pseudonocardia type strains

Strains: 1, Pseudonocardia adelaidensis sp. nov. EUM $221^{\mathrm{T}} ; 2, P$. zijingensis DSM $44774^{\mathrm{T}}$; 3, P. yunnanensis DSM $44253^{\mathrm{T}}$. Data are percentages of total fatty acids and were obtained in this study; only fatty acids detected at $\geqslant 0.5 \%$ of the total are presented. ND, Not detected.

\begin{tabular}{|c|c|c|c|}
\hline Fatty acid & 1 & 2 & 3 \\
\hline iso- $\mathrm{C}_{14: 0}$ & 3.44 & 1.54 & $\mathrm{ND}$ \\
\hline $\mathrm{C}_{14: 0}$ & $\mathrm{ND}$ & 0.51 & 0.92 \\
\hline iso- $\mathrm{C}_{15: 1}$ cis 5 & $\mathrm{ND}$ & $\mathrm{ND}$ & 0.95 \\
\hline iso- $\mathrm{C}_{15: 0}$ & 6.68 & 19.76 & ND \\
\hline anteiso- $\mathrm{C}_{15: 0}$ & 1.05 & 1.74 & $\mathrm{ND}$ \\
\hline $\mathrm{C}_{15: 1}$ cis 6 & 0.90 & 1.50 & $\mathrm{ND}$ \\
\hline iso- $\mathrm{C}_{16: 1} \mathrm{H}$ & 14.71 & 5.01 & $\mathrm{ND}$ \\
\hline iso- $\mathrm{C}_{16: 0}$ & 53.19 & 25.38 & $\mathrm{ND}$ \\
\hline $\mathrm{C}_{16: 1}$ cis 7 & 0.87 & 3.12 & 11.68 \\
\hline $\mathrm{C}_{16: 1}$ cis 5 & $\mathrm{ND}$ & $\mathrm{ND}$ & 1.55 \\
\hline$C_{16: 0}$ & 1.10 & 2.82 & 29.57 \\
\hline 10-Methyl $C_{16: 0}$ & 4.05 & $\mathrm{ND}$ & 1.25 \\
\hline iso- $\mathrm{C}_{17: 1}$ cis 9 & $\mathrm{ND}$ & 9.45 & ND \\
\hline
\end{tabular}

(53.19\%); the fatty acid compositions of strain EUM $221^{\mathrm{T}}$ and related type strains are shown in Table 1. According to the whole-cell fatty acid profile, strain EUM $221^{\mathrm{T}}$ has a similar profile to $P$. zijingensis DSM $44774^{\mathrm{T}}$. However, iso$\mathrm{C}_{17: 1}$ cis 9 was not detected in the whole-cell extract of strain EUM $221^{\mathrm{T}}$, though it was observed in significant amounts $(9.45 \%)$ in the cell extract of P. zijingensis DSM $44774^{\mathrm{T}}$ (Table 1).

Morphological characteristics of strain EUM $221^{\mathrm{T}}$ and reference strains $P$. zijingensis DSM $44774^{\mathrm{T}}$ and $P$. yunnanensis DSM $44253^{\mathrm{T}}$ were observed as described by Shirling \& Gottlieb (1966) on ISP 2, 3, 4, 5 and 7, Bennett's agar, HPDA and nutrient agar (Atlas, 1993). The strain was grown on ISP 4 for 21 days and mounted, unfixed, on a carbon adhesive tab, gold coated and viewed by scanning electron microscopy (ETEC Autoscan 1974). Strain EUM
$221^{\mathrm{T}}$ showed morphology consistent with its membership of the genus Pseudonocardia, with well-developed substrate mycelium but with aerial mycelium formed only on some media, such as ISP 3 and ISP 4. Substrate mycelium was yellowish white on all media used. Cultural characteristics on different media are shown in Table 2. The strain did not produce any diffusible pigment on any of the media tested. Electron microscopy revealed that the mycelium fragmented to form spores, which were straight long rods with a smooth surface (approx. $0.5 \times 1 \mu \mathrm{m}$; Supplementary Fig. S3).

The physiological characteristics of strain EUM $221^{\mathrm{T}}$ and its closest relatives, $P$. zijingensis DSM $44774^{\mathrm{T}}$ and $P$. yunnanensis DSM $44253^{\mathrm{T}}$, were studied together by using the following methods. Carbohydrate utilization was examined as described by Shirling \& Gottlieb (1966). Growth at 15, 27, 37 and $45{ }^{\circ} \mathrm{C}$, at 2, 5, 10 and $15 \%(\mathrm{w} / \mathrm{v})$ $\mathrm{NaCl}$ and at $\mathrm{pH} 4.0-10.0$ was assessed after incubation for 7-21 days on ISP 2 agar at $27{ }^{\circ} \mathrm{C}$, unless otherwise stated (Kurup \& Schmitt, 1973). Decomposition of adenine, hypoxanthine, tyrosine, xanthine, aesculin and hippurate was evaluated according to Gordon et al. (1974). Hydrolysis of casein, starch and gelatin, catalase production and organic acid assimilation were assessed as described by Kurup \& Schmitt (1973). The physiological properties that differentiated strain EUM $221^{\mathrm{T}}$ from $P$. zijingensis DSM $44774^{\mathrm{T}}$ and P. yunnanensis DSM $44253^{\mathrm{T}}$ are shown in Table 3. There were many differences between strain EUM $221^{\mathrm{T}}$ and its closest relative, P. zijingensis DSM $44774^{\mathrm{T}}$. P. zijingensis DSM $44774^{\mathrm{T}}$ utilized arabinose, cellulose and maltose as sole carbon sources while strain EUM $221^{\mathrm{T}}$ could not. Also, P. zijingensis DSM $44774^{\mathrm{T}}$ used cellobiose and lactose weakly, while strain EUM $221^{\mathrm{T}}$ gave a negative test. P. zijingensis DSM $44774^{\mathrm{T}}$ decomposed xanthine and starch and assimilated citrate and tartrate, whereas strain EUM $221^{\mathrm{T}}$ did not. Moreover, EUM $221^{\mathrm{T}}$ could grow at $\mathrm{NaCl}$ concentrations of up to $15 \%(\mathrm{w} / \mathrm{v})$ and growth occurred well at $\mathrm{pH} 6-10$ and at $15-37^{\circ} \mathrm{C}$. On the other hand, $P$. zijingensis DSM $44774^{\mathrm{T}}$ could not tolerate $>5 \% \mathrm{NaCl}$, good growth occurred at $\mathrm{pH} 6-9$ and it grew weakly at $45{ }^{\circ} \mathrm{C}$ (Table 3 ).

Table 2. Cultural characteristics of strain EUM $221^{\top}$

ISP, International Streptomyces Project. Colour determinations based on Kornerup \& Wanscher (1978). Soluble pigments were not detected on any medium.

\begin{tabular}{|llll|}
\hline Medium & Growth & \multicolumn{1}{c|}{ Aerial mycelium } & \multicolumn{1}{c|}{ Substrate mycelium } \\
\hline Yeast extract-malt extract agar (ISP 2) & Good & Not detected & Good, light yellow \\
Oatmeal agar (ISP 3) & Poor & Moderate, white spore & Poor, yellowish white \\
Inorganic salts-starch agar (ISP 4) & Poor & Poor, white spore & Poor, light yellow \\
Glycerol-asparagine agar (ISP 5) & Poor & Not detected & Poor, yellowish white \\
Tyrosine agar (ISP 7) & Moderate & Not detected & Medium, yellowish white \\
Bennett's agar & Moderate & Not detected & Medium, light yellow \\
HPDA & Good & Not detected & Good, pale yellow \\
Nutrient agar & Poor & Not detected & Poor, light yellow \\
\hline
\end{tabular}


Table 3. Characteristics that differentiate strain EUM $221^{\top}$ from related Pseudonocardia type strains

Strains: $1, P$. adelaidensis sp. nov. EUM $221^{\mathrm{T}} ; 2, P$. zijingensis DSM $44774^{\mathrm{T}}$; 3, P. yunnanensis DSM $44253^{\mathrm{T}}$. +, Positive or present; $\mathrm{W}$, weakly positive; - , negative or absent. Data were obtained in this study. All strains could hydrolyse aesculin and hippurate and were catalase-positive. They could assimilate acetate, malate and propionate but could not decompose adenine, casein or gelatin. All strains were able to utilize glucose, glycerol, mannitol and ribose but not dextran or dulcitol as sole carbon sources. All strains could grow at $5 \%(\mathrm{w} / \mathrm{v}) \mathrm{NaCl}, \mathrm{pH} 5-9$ and $15-37{ }^{\circ} \mathrm{C}$.

\begin{tabular}{|c|c|c|c|}
\hline Characteristic & 1 & 2 & 3 \\
\hline \multicolumn{4}{|l|}{ Decomposition of: } \\
\hline Xanthine & - & + & - \\
\hline Hypoxanthine & + & + & - \\
\hline L-Tyrosine & + & + & - \\
\hline Starch & - & + & + \\
\hline \multicolumn{4}{|c|}{ Acid assimilation of: } \\
\hline Benzoate & $\mathrm{w}$ & $\mathrm{w}$ & - \\
\hline Citrate & - & + & + \\
\hline Lactate & + & + & - \\
\hline Tartrate & - & + & - \\
\hline \multicolumn{4}{|l|}{ Growth at: } \\
\hline $10 \% \mathrm{NaCl}$ & $\mathrm{w}$ & - & - \\
\hline $15 \% \mathrm{NaCl}$ & $\mathrm{w}$ & - & - \\
\hline $\mathrm{pH} 10$ & + & $\mathrm{w}$ & + \\
\hline $45^{\circ} \mathrm{C}$ & $\mathrm{w}$ & + & + \\
\hline \multicolumn{4}{|c|}{ Sole carbon sources } \\
\hline Arabinose & - & + & - \\
\hline Cellobiose & - & $\mathrm{w}$ & - \\
\hline Cellulose & - & + & - \\
\hline Galactose & + & + & $\mathrm{w}$ \\
\hline myo-Inositol & + & + & - \\
\hline Lactose & - & $\mathrm{w}$ & - \\
\hline Maltose & - & + & $\mathrm{w}$ \\
\hline Melibiose & + & + & - \\
\hline Mannose & + & + & $\mathrm{w}$ \\
\hline Raffinose & + & + & - \\
\hline Rhamnose & + & + & - \\
\hline Sorbitol & + & + & - \\
\hline Sucrose & + & + & - \\
\hline Trehalose & $\mathrm{w}$ & + & + \\
\hline Xylose & + & + & - \\
\hline
\end{tabular}

Based on this polyphasic study, strain EUM $221^{\mathrm{T}}$ could be readily differentiated from other members of Pseudonocardia species and represents a novel species, for which the name Pseudonocardia adelaidensis sp. nov. is proposed.

\section{Description of Pseudonocardia adelaidensis sp. nov.}

Pseudonocardia adelaidensis (a.de.lai.den'sis. N.L. fem. adj. adelaidensis relating to Adelaide, South Australia, the source of the tree from which the type strain was isolated).
Aerobic, non-acid-alcohol-fast and catalase-positive. Grows well at $15-37{ }^{\circ} \mathrm{C}$, but weakly at $45^{\circ} \mathrm{C}$. Grows at $\mathrm{pH} 6.0-10.0$ and in the presence of $15 \%(\mathrm{w} / \mathrm{v}) \mathrm{NaCl}$. Colonies are small and tough, yellowish white to pale white, and substrate mycelium develops well, but aerial mycelium is rarely formed. Aerial mycelium fragments into long, rod-shaped spores with smooth surfaces (approx. $0.5 \times 1 \mu \mathrm{m}$ ). Diffusible pigments are not produced. Additional physiological properties are listed in Table 3 and the whole-cell fatty acid profile is shown in Table 2 . The DNA G+C content of the type strain is $78.8 \mathrm{~mol} \%$.

The type strain, EUM $211^{\mathrm{T}}\left(=\mathrm{DSM} 45352^{\mathrm{T}}=\mathrm{ACM}\right.$ $5286^{\mathrm{T}}$ ), is an endophyte, isolated from the surface-sterilized stem of a grey box tree (Eucalyptus microcarpa) growing on the Flinders University campus, Adelaide, South Australia.

\section{Acknowledgements}

The authors thank Greg Kirby for his assistance with sampling of native plants, Daniel Jardine for menaquinone analysis, Kerry Gascoigne for SEM visualization and Max Aravena-Roman for performing the MIDI-FAME analysis.

\section{References}

Altschul, S. F., Madden, T. L., Schaffer, A. A., Zhang, J., Zhang, Z., Miller, W. \& Lipman, D. J. (1997). Gapped BLAST and PSI-BLAST: a new generation of protein database search programs. Nucleic Acids Res 25, 3389-3402.

Atlas, R. M. (1993). Handbook of Microbiological Media. Edited by L. C. Parks. Boca Raton, FL: CRC Press.

Bousfield, I. J., Keddie, R. M., Dando, T. R. \& Shaw, S. (1985). Simple rapid methods of cell wall analysis as an aid in the identification of aerobic coryneform bacteria. In Chemical Methods in Bacterial Systematics (Society for Applied Bacteriology Technical Series, vol. 20), pp. 221-236. Edited by M. Goodfellow \& D. E. Minnikin. London: Academic Press.

Collins, M. D., Pirouz, T., Goodfellow, M. \& Minnikin, D. E. (1977). Distribution of menaquinones in actinomycetes and corynebacteria. J Gen Microbiol 100, 221-230.

Conn, V. M. \& Franco, C. M. M. (2004). Analysis of the endophytic actinobacterial population in the roots of wheat (Triticum aestivum L.) by terminal restriction fragment length polymorphism (T-RFLP) and sequencing of $16 \mathrm{~S}$ rRNA clones. Appl Environ Microbiol 70, 17871794.

Coombs, J. T. \& Franco, C. M. M. (2003). Isolation and identification of actinobacteria from surface-sterilized wheat roots. Appl Environ Microbiol 69, 5603-5608.

Euzéby, J. P. (1997). List of bacterial names with standing in nomenclature: a folder available on the Internet. Int J Syst Bacteriol 47, 590-592. http://www.bacterio.cict.fr

Felsenstein, J. (1985). Confidence limits on phylogenies: an approach using the bootstrap. Evolution 39, 783-791.

Gonzalez, J. M. \& Saiz-Jimenez, C. (2005). A simple fluorimetric method for the estimation of DNA-DNA relatedness between closely related microorganisms by thermal denaturation temperatures. Extremophiles 9, 75-79. 
Gordon, R. E., Barnett, D. A., Handerhan, J. E. \& Pang, C. H.-N. (1974). Nocardia coeliaca, Nocardia autotrophica, and the nocardin strain. Int J Syst Bacteriol 24, 54-63.

Hasegawa, T., Takizawa, M. \& Tanida, S. (1983). A rapid analysis for chemical grouping of aerobic actinomycetes. J Gen Appl Microbiol 29, 319-322.

Henssen, A. (1957). Beitrage zur Morphologie und Systematik der thermophilen Actinomyceten. Arch Mikrobiol 26, 373-414 (in German).

Joseph, S. J., Hugenholtz, P., Sangwan, P., Osborne, C. A. \& Janssen, P. H. (2003). Laboratory cultivation of widespread and previously uncultured soil bacteria. Appl Environ Microbiol 69, 72107215.

Kaewkla, O. \& Franco, C. M. M. (2010). Nocardia callistridis sp. nov., an endophytic actinobacterium isolated from a surface-sterilized root of an Australian native pine tree. Int J Syst Evol Microbiol 60, 15321536.

Kimura, M. (1980). A simple method for estimating evolutionary rate of base substitutions through comparative studies of nucleotide sequences. J Mol Evol 16, 111-120.

Kluge, A. G. \& Farris, J. S. (1969). Quantitative phyletics and the evolution of anurans. Syst Zool 18, 1-32.

Kornerup, A. \& Wanscher, J. H. (1978). Methuen Handbook of Colour, 3rd edn. Edited by D. Pavey. Fakenham, UK: Cox \& Wyman.

Kurup, P. V. \& Schmitt, J. A. (1973). Numerical taxonomy of Nocardia. Can J Microbiol 19, 1035-1048.

Lee, S. D., Kim, E. S. \& Hah, Y. C. (2000). Phylogenetic analysis of the genera Pseudonocardia and Actinobispora based on $16 \mathrm{~S}$ ribosomal DNA sequences. FEMS Microbiol Lett 182, 125-129.

McVeigh, H. P., Munro, J. \& Embley, T. M. (1994). The phylogenetic position of Pseudomycolata halophobica (Akimov et al. 1989) and a proposal to reclassify it as Pseudonocardia halophobica. Int J Syst Bacteriol 44, 300-302.

Mesbah, M., Premachandran, U. \& Whitman, W. B. (1989). Precise measurement of the $\mathrm{G}+\mathrm{C}$ content of deoxyribonucleic acid by highperformance liquid chromatography. Int J Syst Bacteriol 39, 159-167.

Minnikin, D. E., Alshamaony, L. \& Goodfellow, M. (1975). Differentiation of Mycobacterium, Nocardia and related taxa by thin-layer chromatographic analysis of whole-organism methanolysates. J Gen Microbiol 88, 200-204.
Minnikin, D. E., Hutchinson, I. G. \& Caldicott, A. B. (1980). Thin layer chromatography of methanolysates of mycolic acid containing bacteria. J Chromatogr A 188, 221-233.

Reichert, K., Lipski, A., Pradella, S., Stackebrandt, E. \& Altendorf, K. (1998). Pseudonocardia asaccharolytica sp. nov. and Pseudonocardia sulfidoxydans sp. nov., two new dimethyl disulfide-degrading actinomycetes and emended description of the genus Pseudonocardia. Int $J$ Syst Bacteriol 48, 441-449.

Rosselló-Mora, R. \& Amann, R. (2001). The species concept for prokaryotes. FEMS Microbiol Rev 25, 39-67.

Saitou, N. \& Nei, M. (1987). The neighbor-joining method: a new method for reconstructing phylogenetic trees. Mol Biol Evol 4, 406-425.

Sasser, M. (2001). Identification of bacteria by gas chromatography of cellular fatty acids, MIDI Technical Note 101. Newark, DE: MIDI Inc.

Schoenborn, L., Yates, P. S., Grinton, B. E., Hugenholtz, P. \& Janssen, P. H. (2004). Liquid serial dilution is inferior to solid media for isolation of cultures representative of the phylum-level diversity of soil bacteria. Appl Environ Microbiol 70, 4363-4366.

Shirling, E. B. \& Gottlieb, D. (1966). Methods for characterization of Streptomyces species. Int J Syst Bacteriol 16, 313-340.

Tamura, K., Dudley, J., Nei, M. \& Kumar, S. (2007). MEGA4: molecular evolutionary genetics analysis (MEGA) software version 4.0. Mol Biol Evol 24, 1596-1599.

Thompson, J. D., Gibson, T. J., Plewniak, F., Jeanmougin, F. \& Higgins, D. G. (1997). The CLUSTAL_X Windows interface: flexible strategies for multiple sequence alignment aided by quality analysis tools. Nucleic Acids Res 25, 4876-4882.

Uchida, K., Kudo, T., Suzuki, K. \& Nakase, T. (1999). A new rapid method of glycolate test by diethyl ether extraction, which is applicable to a small amount of bacterial cells of less than one milligram. J Gen Appl Microbiol 45, 49-56.

Warwick, S., Bowen, T., McVeigh, H. \& Embley, T. M. (1994). A phylogenetic analysis of the family Pseudonocardiaceae and the genera Actinokineospora and Saccharothrix with 16S rRNA sequences and a proposal to combine the genera Amycolata and Pseudonocardia in an emended genus Pseudonocardia. Int J Syst Bacteriol 44, 293-299.

Wayne, L. G., Brenner, D. J., Colwell, R. R., Grimont, P. A. D., Kandler, O., Krichevsky, M. I., Moore, L. H., Moore, W. E. C., Murray, R. G. E. \& other authors (1987). International Committee on Systematic Bacteriology. Report of the ad hoc committee on reconciliation of approaches to bacterial systematics. Int J Syst Bacteriol 37, 463-464. 